\title{
Greening the canned peach production
}

\author{
Dimitrios Folinas $^{1}$, Dimitrios Aidonis ${ }^{1}$, Panayotis Karayannakidis ${ }^{1}$
}

\section{N F O}

Received 25 Nov 2014

Accepted 29 Dec 2014

Available on-line 14 Jan 2015

Responsible Editor: M. Herdon

\section{Keywords:}

Food Supply Chain, Canned Peach, Lean thinking, Value Stream Mapping, Green Supply Chain.

\begin{abstract}
$\underline{\text { A B S T R A C T }}$
The paper proposes an approach for measuring the environmental performance of canned peach production based on Lean Thinking techniques. Among the various stages of a typical production line of canned peach, peeling and pasteurizing are the most energy consuming. In these stages specific actions have been suggested and applied. Considering the findings that were observed following the implementation of these actions, the research project provided viable evidence that Lean techniques a positive impact in the production and logistics operations.
\end{abstract}

\section{Introduction}

Lean thinking is a set of principles, techniques and tools all aimed at minimizing non-value adding processes, which are characterized by wastes of different forms. According to Emiliani and Stec (2004) wastes are classified as follows: Overproduction, Waiting, Transportation, Processing, Inventories: raw material, work-in-process, and finished goods, Moving: both operator and machine, and Defects: defective products or process outputs.

Lean thinking tools have recorded significant successes resulting in a worldwide and trans-sectorial recognition including both products and services. Some of the available and known tools used are: Takt Time, Kaizen, Statistical Process Control, Poka-Yoke, 5S, Value Stream Mapping (VSM), Total Quality Management, Kanban, and Jidoka, among many others. Plenert (2007), as well as, Abdulmalek and Rajgopal (2007), emphasize especially the significance and usefulness of the VSM as a key tool of Lean thinking while Singh, Garg and Sharma (2010) provide an extended literature review of the VSM in a wide range of sectors. VSM is a visual representation of processes within a pathway and can be considered as a visual map of all the activities, illustrating how they linked to each other, and information such as timing and resources. It aims identifying all the value-added and nonvalue-added (waste) activities, as an opportunity to remove non-value-add steps and eliminate waste through problem solving, to standardize and improve value-added processes but mainly to eliminate waste. Moreover, it includes two diagrams / value stream maps; the first value stream map records the current state of the process line and the future state map that shows what the process line would look like after improvements / elimination of wastes are made.

In this paper, the study is focused on the agrifood sector. This sector is characterized by real constraints on natural resources, as well as, high production costs, higher risks, and competition for resources by the producers (Beresford and Pettit, 2004; Chow, Heaver and Henriksson, 1994; Rothenberg, Pil and Maxwell, 2001). In the past managers in the examined sector aimed to minimize costs while enhancing the quality of the end product. There is always a high need for decreasing the lead time due to the nature of the products and this decrease could easily translate to lower financial costs and lower inventory management cost. Moreover, there is also the "consumers' awareness need" ,accordingly consumers must be better informed and better educated in terms food quality, food safety and food nutrition issues. Today, one additional objective is added; to identify the factors that have environmental impacts in the targeted supply chain by decreasing waste. Referring to the value stream maps, in the past, the time it takes to produce a product and the proportion of that time that is value

\footnotetext{
${ }^{1}$ Dimitrios Folinas, Dimitrios Aidonis, Panayotis Karayannakidis

Department of Logistics, Technological Educational Institute of Central Macedonia dfolinas@gmail.com
} 
added - or the time spent actually working on the product was estimated; although today, the focus is also on the resources consumed and waste generated in making the product.

In the literature there have been empirical and theoretical researches about the deployment of lean methods in the agrifood sector having two general objectives: first, to reduce the operation costs and second, the environmental emission. The following table summarizes the research initiatives that refer to the second objective.

Table 1. Relative studies regarding the application of lean thinking techniques and practices for waste identification in the agrifood section

\begin{tabular}{|c|c|c|c|}
\hline $\begin{array}{l}\text { Author(s) / } \\
\text { Publication year }\end{array}$ & Title & Research objective(s) & $\begin{array}{l}\text { Supply chain } \\
\text { stage }\end{array}$ \\
\hline $\begin{array}{l}\text { Venkat and } \\
\text { Wakeland (2006) }\end{array}$ & $\begin{array}{l}\text { Is Lean Necessarily } \\
\text { Green? }\end{array}$ & $\begin{array}{l}\text { Investigation of the } \\
\text { environmental performance } \\
\text { of lean supply chains using } \\
\text { carbon dioxide emissions as } \\
\text { the key performance } \\
\text { indicator }\end{array}$ & $\begin{array}{l}\text { Complete supply } \\
\text { chain }\end{array}$ \\
\hline $\begin{array}{l}\text { Simons and Mason } \\
\text { (2002) }\end{array}$ & $\begin{array}{l}\text { Environmental and } \\
\text { Transport Supply } \\
\text { Chain Evaluation } \\
\text { with Sustainable } \\
\text { Value Stream } \\
\text { Mapping }\end{array}$ & $\begin{array}{l}\text { Examination of the } \\
\text { emission characteristics of } \\
\text { a generic food supply chain } \\
\text { which includes both } \\
\text { transportation and cold } \\
\text { storage }\end{array}$ & $\begin{array}{l}\text { Transportation / } \\
\text { distribution of } \\
\text { final products } \\
\text { and storing in } \\
\text { distribution } \\
\text { centres }\end{array}$ \\
\hline $\begin{array}{l}\text { Cox and } \\
\text { Chicksand (2005) }\end{array}$ & $\begin{array}{l}\text { The limits of Lean } \\
\text { Management } \\
\text { Thinking: Multiple } \\
\text { Retailers and Food } \\
\text { and Farming Supply } \\
\text { Chains }\end{array}$ & $\begin{array}{l}\text { Investigation if there are } \\
\text { limits to the application of } \\
\text { lean management thinking } \\
\text { in complex supply chains }\end{array}$ & $\begin{array}{l}\text { Complete supply } \\
\text { chain }\end{array}$ \\
\hline Tanco et al. (2013) & $\begin{array}{l}\text { Applying lean } \\
\text { techniques to nougat } \\
\text { fabrication: a } \\
\text { seasonal case study }\end{array}$ & $\begin{array}{l}\text { Discussion of the } \\
\text { applicability of lean } \\
\text { manufacturing's knowledge } \\
\text { to a different environment: } \\
\text { a seasonal food industry }\end{array}$ & $\begin{array}{l}\text { Complete supply } \\
\text { chain }\end{array}$ \\
\hline
\end{tabular}

In the recent years a number of researches have focused on the application of Value Stream Mapping for supporting the greening efforts. A great work has been done by the United States Environmental Protection Agency (USEPA) when they first introduced the Environmental Value Stream Mapping (EVSM) method at 2007, which has all the characteristics of its parent -Value Stream Mapping- but additionally environmental issues and the usage of material or energy.

Another organization in US; the USA Environmental Protection Agency (or EPA), at 2007 proposed the Energy Value Stream Mapping (EnVsm) as a tool which has the information and data about energy usage of each process item as well as its regular lean data in the typical format (VSM). The aim of the above tool is to have both data from the value added action and process beside the energy usage or waste in a same picture. Therefore, the decision makers can improve the future state of the process in a way that has better and more efficiency in both ways; lean principle and energy saving (EPA, 2007). 
Based on the above studies and initiatives this paper explores the application of the VSM tool so as to determine the waste that have environmental impact in a specific agrifood supply chain; the production of the canned peach. The main objective of this paper is to propose a four-step approach for measuring the environmental performance of supply chains in the food sector based on Lean thinking techniques so as to identify sources of waste in the selected supply chain. Each step aimed at eliminating non value adding steps in order to reduce on the length of the value stream which subsequently would contribute to the reduction of the total process, lead and customer query cycle times and consequently the energy consumption and emissions. Specifically, VSM is suggested for determining waste, in terms of measuring the water, energy and lead time of the production process.

\section{Application of VSM in canned peach production}

Value Stream Mapping (VSM) diagrams are used in order to develop visual representations of the canned peach production. First, the Current State Map (CSM) is developed to represent the production "as-is" in order to identify the highest sources of waste (non-value added activity) in the value stream of the examined process, as well as, to develop an implementation plan for lean techniques with the development of the Future State Map (FSM).

Based on Rother and Shook (2003) proposed methodology and following studies such as Lasa, Laburu and Vila (2008), Seth D., Seth N. and Goel, (2008), Belokar, Kumar and Kharb (2012) a fourstep approach is proposed including the following steps:

- Step 1: Selection of agrifood supply chain processes to be value-streamed.

- Step 2: Development of the Current State Map (CSM) of the selected processes in the agrifood supply chain.

- Step 3: Development of the Future State Map (FSM).

- Step 4: Development of the Action Plan (AP).

\subsection{Step 1: Selection of agrifood supply chain processes to be value-streamed}

A typical process for the production of canned peach is illustrated at the Figure 1 (SuperPro Designer, version 9.0; Intelligen, Inc., Scotch Plains, NJ, USA was used, to document the examined canned peach production line) and consists of the following stages:

Initially, the fruits are delivered to the peach processing plants by lorries and are usually placed in crates, boxes or small punnets depending on their susceptibility to damage. After weighing, samples are taken from each load to ensure the quality is suitable for processing and determine the price of the raw material. Sampling also provides insight regarding the ripening stage of peaches and whether they should be stored (usually in a cool dry environment) or processed immediately by canning (Burrows, 1996). Once peaches are introduced in the production lines, they are immersed into high capacity holding tanks filled with warm water $\left(20-30^{\circ} \mathrm{C}\right)$. The residence time of peaches in warm water ranges from 10-15 min. This processing step aims at removing foreign materials, such as leaves, insects, debris etc. The washed fruits are then cut in halves using cutting machines, while the kernels are being simultaneously removed (Karagiovannis, 2014).

Peaches may be peeled by hand, as well as by chemical or mechanical methods. However, the most commonly employed method for peeling is the immersion of fruits in an alkaline solution (chemical method), using sodium or potassium hydroxide, at $95{ }^{\circ} \mathrm{C}$ for $4-5 \mathrm{~min}$. A visual inspection is deemed necessary to remove any remaining skin from the fruit, once peeling is completed. Following peeling, the fruits are washed with abundant water to remove any residual chemicals from the flesh. Usually, the washing process is carried out at $25{ }^{\circ} \mathrm{C}$ for $1 \mathrm{~min}$. The washed fruits are then sorted according to size. This is followed by cup-up and cup-down, in order to remove any residual kernels and improve quality of the product. Fruits that are undersized or damaged are rejected and destined for other types of products, such as peach puree. The cans are then filled with the peeled peach halves with a filling machine. Correct filling of cans is not only desirable for economic reasons, but also technically important (Burrows, 1996; Karagiovannis, 2014).

The syrup is prepared by dissolving sugar in water and maintaining the temperature of the resulting solution at $65{ }^{\circ} \mathrm{C}$ prior filling. The concentration of the solution, however, depends on the cultivar used 
for peach canning. Typically, cultivars with high soluble and total solids require less sugar to sweeten the product to the desired level (Sistrunk, 1985). The fruits are covered with syrup using a vacuum syruping machine and the mixture (peach halves and syrup) is subjected to degassing in order to remove air, which aims at reducing microbial growth and, therefore, extending the shelf life of the final product (Joshi and Bhutani, 1995).

The filled cans are then closed by placing a lid on top of each can and sealing it to the body (double seam formation). Afterwards, the product is pasteurized until the temperature at the center reaches 85 ${ }^{\circ} \mathrm{C}$ and cooled down at room temperature. The final product is being held in a dry environment for 3 weeks, which allows the contents of the can to reach equilibrium. Can labelling takes place immediately after placing an order (Karagiovannis, 2014).

Gas emissions are produced practically exclusively by the combustion of gas/oil for heating up water during the initial washing, the alkaline solution during peeling and the syrup prior to filling the cans, as well as for steam generation and degassing. The liquid wastes that are formed during the canned peach production process include dilute aqueous solutions that contain sugars and alkali, whereas the solid wastes consist mostly of kernels and peels.

Based on the above description of the canned peach production the following discrete processes are identified: factory reception, washing, cutting in halves and removing the kernels, peeling (removal of residual chemicals), washing, sorting, cup-up, cup-down, filling with fruit, addition of syrup, degassing, closing, pasteurizing, cooling pelletizing and labeling. But, are all these processes potentially waste sources?

In order to identify the processes to be value-streamed we need to evaluate them based on specific criteria. This problem was the objective of many research initiatives in the past (Davenport, 1993; Dervitsiotis, 2006; Madison, 2005; Ioannou, 2005; Laguna and Marklund, 2004; Folinas, Kelemis and Manikas, 2011). Significant contribution was made by EPA (2007). In the 'The Lean and Energy Toolkit' a table was summarized in a straightforward manner the environmental impacts for every of the 7 typical types of waste (Over-production, Inventory, Defects, Transportation, Motion, Overprocessing, and Waiting). Furthermore, in the next year Hanes et al. (2008) identified the corresponding causes and effects (Table 2). 


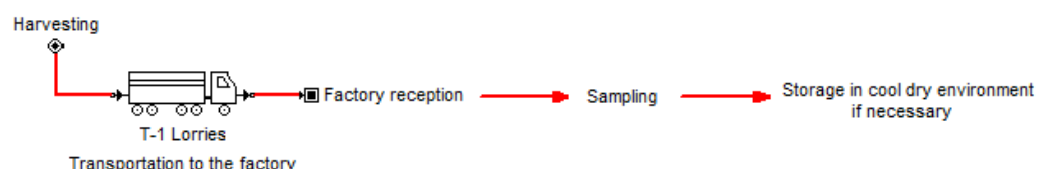

Transportation to the factory
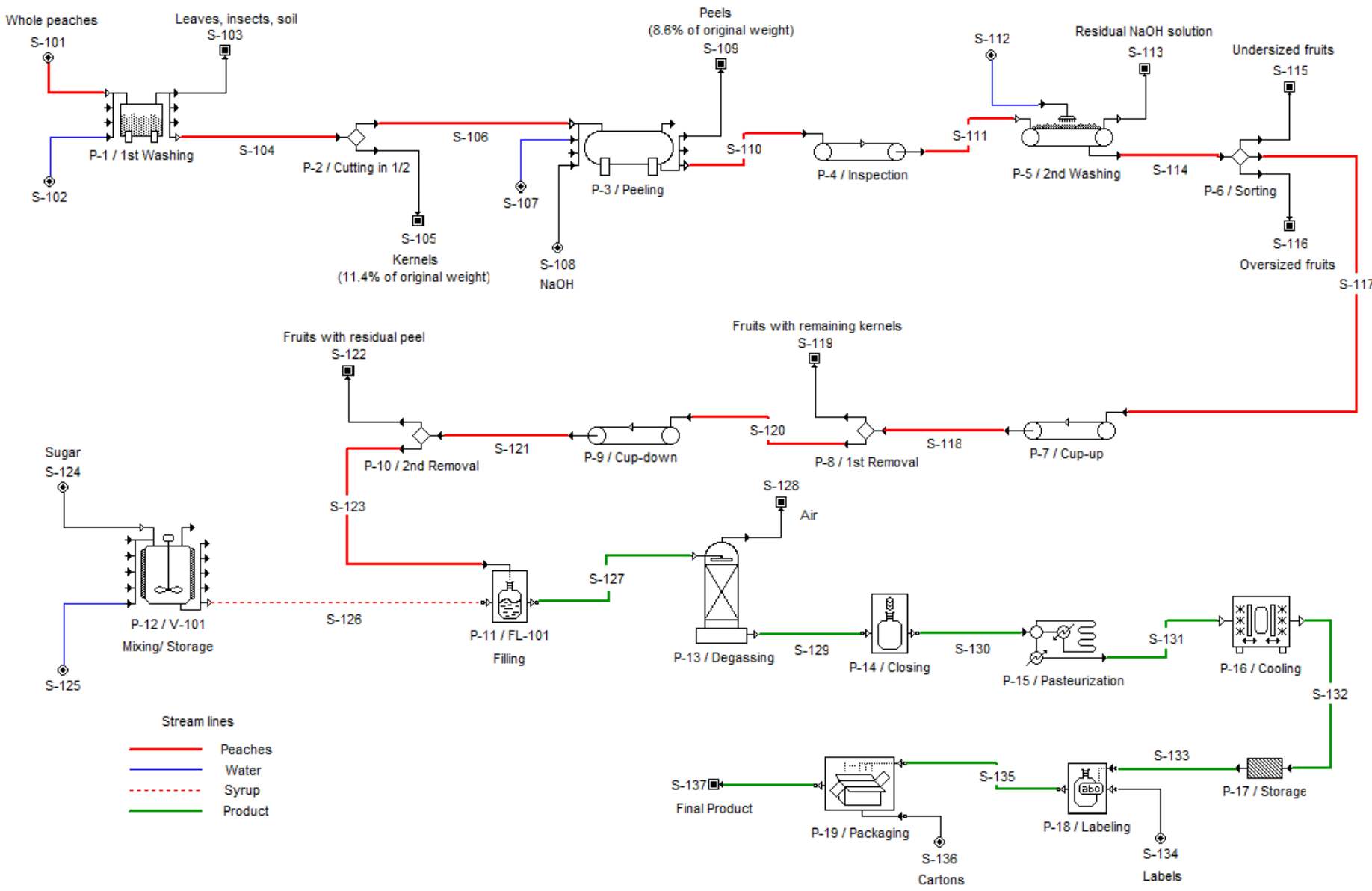

Figure 1. Canned production process 
Table 2. Effect, cause and environmental impact of the seven wastes

Waste (Muda) Lean Management

\begin{tabular}{|c|c|c|c|}
\hline & \multicolumn{3}{|c|}{ Environmental (EPA, 2007) General (Hines et al., 2008) } \\
\hline & Environmental Impact & Effect & Cause \\
\hline $\begin{array}{l}\text { Over- } \\
\text { production }\end{array}$ & $\begin{array}{l}\text { - More raw materials } \\
\text { and energy consumed } \\
\text { in making the } \\
\text { unnecessary products } \\
\text { - Extra products may } \\
\text { spoil or become } \\
\text { obsolete requiring } \\
\text { disposal } \\
\text { - Extra hazardous } \\
\text { materials used result } \\
\text { in extra emissions, } \\
\text { waste disposal, } \\
\text { worker exposure, etc. }\end{array}$ & $\begin{array}{l}\text { Human movement } \\
\text { not necessary, non- } \\
\text { ergonomic work } \\
\text { position, loss of } \\
\text { tools }\end{array}$ & $\begin{array}{l}\text { Wrong information flow, } \\
\text { wrong production schedule }\end{array}$ \\
\hline Inventory & 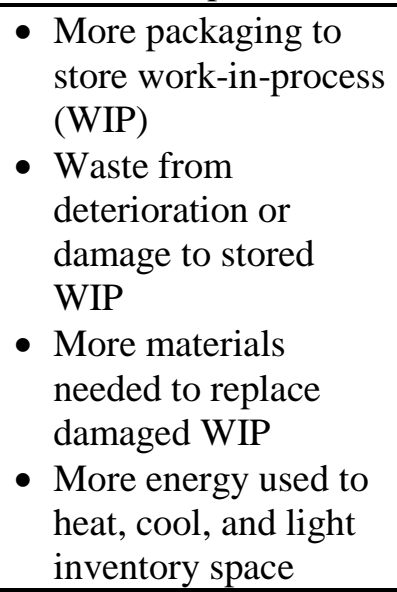 & $\begin{array}{l}\text { Increase of leading } \\
\text { time, cost }\end{array}$ & $\begin{array}{l}\text { Product or process } \\
\text { inefficiency, long set-up } \\
\text { times, push production } \\
\text { approach, low customer } \\
\text { service }\end{array}$ \\
\hline Defects & $\begin{array}{l}\text { - Raw materials and } \\
\text { energy consumed in } \\
\text { making defective } \\
\text { products } \\
\text { - Defective } \\
\text { components require } \\
\text { recycling or disposal } \\
\text { - More space required } \\
\text { for rework and repair, } \\
\text { increasing energy use } \\
\text { for heating, cooling, } \\
\text { and lighting }\end{array}$ & $\begin{array}{l}\text { Product with } \\
\text { defects that require } \\
\text { rework or disposal }\end{array}$ & $\begin{array}{l}\text { Design error, machine } \\
\text { setup wrong process } \\
\text { production and quality } \\
\text { protocol assessment }\end{array}$ \\
\hline $\begin{array}{l}\text { Transportatio } \\
n \text { and motion }\end{array}$ & $\begin{array}{l}\text { - More energy use for } \\
\text { transport } \\
\text { - Emissions from } \\
\text { transport } \\
\text { - More space required } \\
\text { for WIP movement, } \\
\text { increasing lighting, } \\
\text { heating, and cooling } \\
\text { demand and energy } \\
\text { consumption }\end{array}$ & $\begin{array}{l}\text { Human movement } \\
\text { not necessary, non- } \\
\text { ergonomic work } \\
\text { position, loss of } \\
\text { tools } \\
\text { Increase of leading } \\
\text { time, cost }\end{array}$ & $\begin{array}{l}\text { Wrong layout of the } \\
\text { facility and/or of the } \\
\text { workplace } \\
\text { Excess transport of WIP or } \\
\text { products }\end{array}$ \\
\hline
\end{tabular}




\begin{tabular}{|c|c|c|c|}
\hline & $\begin{array}{l}\text { - More packaging } \\
\text { required to protect } \\
\text { components during } \\
\text { movement } \\
\text { - Damage and spills } \\
\text { during transport } \\
\end{array}$ & & \\
\hline Process & $\begin{array}{l}\text { - } \text { More parts and raw } \\
\text { materials consumed } \\
\text { per unit of production } \\
\text { - Unnecessary } \\
\text { processing increases } \\
\text { wastes, energy use, } \\
\text { and emissions } \\
\end{array}$ & $\begin{array}{l}\text { Process steps not } \\
\text { required to } \\
\text { produce the item }\end{array}$ & $\begin{array}{l}\text { Procedures and methods } \\
\text { not designed to meet } \\
\text { production requirements, } \\
\text { machine set-up too long }\end{array}$ \\
\hline Waiting & $\begin{array}{l}\text { - Potential material } \\
\text { spoilage or } \\
\text { component damage } \\
\text { causing waste } \\
\text { - Wasted energy from } \\
\text { heating, cooling, and } \\
\text { lighting during } \\
\text { production downtime }\end{array}$ & $\begin{array}{l}\text { Delays with stock- } \\
\text { outs, equipment } \\
\text { downtime, } \\
\text { capacity } \\
\text { bottlenecks, } \\
\text { information } \\
\text { transfer }\end{array}$ & $\begin{array}{l}\text { Inefficient information } \\
\text { flow, work organization } \\
\text { not efficient, maintenance } \\
\text { program not adequate }\end{array}$ \\
\hline
\end{tabular}

After synthesizing the above studies we concluded to the following six criteria:

1. Processes that require significant amounts of inputs / resources, such as pounds of materials used, pounds of hazardous materials used, gallons of water used, gallons of water consumed, watts of energy used, etc.

2. Processes that emit significant amounts of outputs, such as pounds of solid waste generated, pounds of hazardous waste generated, pounds of air pollution emitted, etc.

3. Processes requiring environmental permits or reporting to environmental agencies, and

4. Processes that include special pollution control equipment and/or specialized infrastructure.

5. Processes that potentially affect the environmental consciousness and sensitiveness of the producers.

6. Processes that potentially affect the environmental consciousness and sensitiveness of the consumers.

Based on the proposed six criteria we used both primary and secondary data analysis to evaluate the level of the environmental impact of the processes that were emerged by the description of the canned peach production. These approaches were applied in one of the biggest canned production company in Northern Greece that follows the typical production of the targeting product (The main facts and assumptions are presented in the Appendix - Table 5). First, a number of interviews were arranged with key persons in the Production and Quality Assurance departments. Respondents took into account the effects, causes and environmental impact of the seven wastes as depicted in Table 1 and evaluated the processes using four values: Not significant, Low, Medium and High (significance). Data extracted from both departments and referred to the production line of the last 3 years were collected and analyzed. A number of reports were created and given to employees / respondents to make a more reliable evaluation. Table 3 presents and evaluates the processes that were identified with the above criteria according to the responses (modes values are presented). 
Table 3. Identifying the processes to be value-streamed

\begin{tabular}{|lcccccc|}
\hline Criteria & $\begin{array}{c}\text { Inputs / } \\
\text { resources }\end{array}$ & Outputs & Agencies & $\begin{array}{c}\text { Equipment } \\
\text { need }\end{array}$ & $\begin{array}{c}\text { Producers } \\
\text { consciousness }\end{array}$ & $\begin{array}{c}\text { Consumers } \\
\text { consciousness }\end{array}$ \\
\hline Receiving & $\mathrm{M}$ & $\mathrm{M}$ & $\mathrm{M}$ & $\mathrm{H}$ & $\mathrm{L}$ & $\mathrm{L}$ \\
\hline Washing & $\mathrm{L}$ & $\mathrm{M}$ & $\mathrm{L}$ & $\mathrm{L}$ & $\mathrm{L}$ & $\mathrm{L}$ \\
\hline Cutting & $\mathrm{L}$ & $\mathrm{M}$ & $\mathrm{L}$ & $\mathrm{L}$ & $\mathrm{L}$ & $\mathrm{L}$ \\
\hline Peeling & $\mathrm{H}$ & $\mathrm{H}$ & $\mathrm{H}$ & $\mathrm{H}$ & $\mathrm{M}$ & $\mathrm{M}$ \\
\hline Washing & $\mathrm{L}$ & $\mathrm{M}$ & $\mathrm{L}$ & $\mathrm{L}$ & $\mathrm{L}$ & $\mathrm{L}$ \\
\hline Sorting & $\mathrm{L}$ & $\mathrm{L}$ & $\mathrm{L}$ & $\mathrm{L}$ & $\mathrm{L}$ & $\mathrm{L}$ \\
\hline Cup Up & $\mathrm{L}$ & $\mathrm{M}$ & $\mathrm{L}$ & $\mathrm{L}$ & $\mathrm{L}$ & $\mathrm{L}$ \\
\hline Cup Down & $\mathrm{L}$ & $\mathrm{M}$ & $\mathrm{L}$ & $\mathrm{L}$ & $\mathrm{L}$ & $\mathrm{L}$ \\
\hline Filling (Fruit) & $\mathrm{M}$ & $\mathrm{M}$ & $\mathrm{M}$ & $\mathrm{M}$ & $\mathrm{L}$ & $\mathrm{L}$ \\
\hline Syrup production & $\mathrm{H}$ & $\mathrm{H}$ & $\mathrm{H}$ & $\mathrm{H}$ & $\mathrm{M}$ & $\mathrm{M}$ \\
\hline Addition & $\mathrm{M}$ & $\mathrm{M}$ & $\mathrm{M}$ & $\mathrm{M}$ & $\mathrm{M}$ & $\mathrm{M}$ \\
\hline Degassing & $\mathrm{H}$ & $\mathrm{H}$ & $\mathrm{H}$ & $\mathrm{H}$ & $\mathrm{M}$ & $\mathrm{M}$ \\
\hline Closing & $\mathrm{L}$ & $\mathrm{L}$ & $\mathrm{L}$ & $\mathrm{L}$ & $\mathrm{L}$ & $\mathrm{L}$ \\
\hline Pasteurizing & $\mathrm{H}$ & $\mathrm{H}$ & $\mathrm{M}$ & $\mathrm{M}$ & $\mathrm{M}$ & $\mathrm{M}$ \\
\hline Cooling & $\mathrm{L}$ & $\mathrm{L}$ & $\mathrm{L}$ & $\mathrm{L}$ & $\mathrm{L}$ & $\mathrm{L}$ \\
\hline Palletizing/Labeling & $\mathrm{L}$ & $\mathrm{L}$ & $\mathrm{L}$ & $\mathrm{L}$ & $\mathrm{L}$ & $\mathrm{L}$ \\
\hline
\end{tabular}

According to the above findings all the above processes were selected for the development of current and future stream maps (Steps 2 and 3).

\subsection{Step 2: Development of the Current State Map (CSM) of the selected processes.}

In order to develop the CSM of the examined product, calculations were made in every process that was identified in the previous step. In general, through this step both qualitative and quantitative data were collected for the identification of waste. The data were categorized into two groups: 1) General information including the following issues: cycle time, change over time and up time, processing time for each of the production and logistics tasks performed, reliability of equipment used and availability of such materials as packaging, average waiting time for each order, number of operators, etc., and specific information, which can include the following: pounds of materials used, pounds of hazardous materials used, gallons of water used, gallons of water consumed, watts of energy used (watt-hour per pound of output), BTUS of energy used, pounds of solid waste generated, pounds of hazardous waste generated, pounds of air pollution emitted and gallons of wastewater treated. This study was focused on the environmental aspects of the targeted procedure and was referred to litres of water and energy used (electricity and steam).

Since, the production is already automated no further improvement of the total process time could be achieved. Additionally, since the last 5 years the company have successfully used the make-toorder policy there hasn't been any stock remaining. The company receives the orders from June to August and produces in September the required quantities. Much effort has been applied in practice by cooperatively working with the peach producers so as to establish a smooth deliver procedure.

Therefore the study focuses on $\mathrm{CO} 2$ emissions and water usage. First, regarding the water usage there are two stages where there is significant water consumption: washing for removing foreign materials (leaves, insects, etc.) and then (after the peeling) to remove any residual chemicals from the flesh. In both cases a fixed and predefined quantity of water based on the needs and it is estimated straightforwardly and in an ad-hoc basis. Manufacturer maintained and used a specialized instrument for filtering the water in the above two stages so as to clean the shop-floor areas.

Second, regarding the energy the following table presents the steam and electricity usage. 
Table 4. Estimating water and energy used

\begin{tabular}{|c|c|c|}
\hline & $\begin{array}{c}\text { Electricity used ( } k W h / p e r \\
\text { production line) }\end{array}$ & $\begin{array}{c}\text { Steam used (\% of the } \\
\text { total use) }\end{array}$ \\
\hline Receiving & - & - \\
\hline Washing & 90 & - \\
\hline Cutting & 90 & - \\
\hline Peeling & 1650 & 30 \\
\hline Washing & 1104 & - \\
\hline Sorting & 1822 & - \\
\hline Cup Up & 5520 & - \\
\hline Cup Down & 5520 & - \\
\hline Filling (Fruit) & 5520 & - \\
\hline Syrup production & 2208 & 10 \\
\hline Addition & 5520 & - \\
\hline Degassing & 5520 & 60 \\
\hline Closing & 5520 & - \\
\hline Pasteurizing & 5520 & - \\
\hline Cooling & 4968 & - \\
\hline Palletizing/Labelling & - & - \\
\hline
\end{tabular}

According to the estimations some processes that were measured have some of the environmental impacts that were presented in the Table 2 but all have time and labour inputs such as the number of employees / shifts, cycle time (c/t), operation time (o/t), set up time, scrap rate, rework rate, etc. Figure 2 in the Appendix presents the Current State Map (created with MSVisio).

In the bottom of the map there are three lines that represent: 1) Total lead time and value added time, 2) Amount (litres) of water used (top line) and amount (litres) of water needed (bottom line) per day and per process, 3) kWh's of energy used (top line) and kWh's of energy needed (bottom line) per day and per process: for measuring energy consumption a power measuring device (the power consumption of a machine for machining a part or a batch over a particular time in 24 hours) and a data logger were used. Since the examined production process is fully automated and especially from Storage to Packaging, Total Lead Time and Valued Added Time are not considerably different.

Therefore, and based to Table 2, Inventory, Transportation and motion waste, as well as, the Waiting waste are not critical. Furthermore, according to the historical data maintained by the Quality Control company's department, the Defect level (caused by scrap rate, design error, machine setup, wrong process production and quality protocol assessment) is very low ( $\sim .5 \%$ per lot) so this waste is also not critical.

In contrast, there are two processes that have significant environmental impact in terms of water and energy used: Peeling and subsequent washing and pasteurizing. Moreover, one waste according to Table 2 (Process), has been selected for a more detailed examination. Based on the above the Current State Map (CSM) is created for the examined production process as depicted in the Appendix (Figure 2).

\subsection{Step 3: Development of the Future State Map.}

The main objective of this step is the identification of processes with main environmental, health, and safety opportunities on the CSM. But most of all, this step includes the identification of the appropriate practices, technologies and tools in order to minimize waste. According to the findings of the previous step, authors and the two managers of the manufacturer have focused on one waste: Process and specifically on two processing steps: peeling and subsequent washing and pasteurizing. Based on the above, the following practices were proposed (Figure 3 in the Appendix).

Among the various stages of a typical production line of canned peach, peeling and pasteurizing are the most energy consuming. Furthermore, the use of chemical compounds during peeling, such as potassium and sodium hydroxide, will increase the chemical load of wastes, as well as the production 
cost, since the alkaline solutions are further enforced by the addition of the above compounds due to dilution by the expelled fruit juice.

It is well established that peeling of fruits and vegetables can be achieved by steaming, provided that the steam used, is food grade. Peeling by steaming instead of chemical peeling, automatically minimizes the amount of water during the second washing for removing any residual chemicals, having great benefits regarding water consumption. Moreover, the condensed steam after peeling may be used for preheating the syrup, prior to filling the cans, making the whole process energy efficient. Another point to be made is that most of the holding tanks and piping, in the peach canning industries in Greece, are lacking insulation and this is of significant importance for minimizing the energy losses, especially in the stages where heating and cooling are involved. Finally, peach kernels may be exploited by the industries for energy production (biomass boilers) to cover the energy requirements of other small production lines, for products such as peach juice and puree.

\section{Step 4: Development of the Action Plan (AP)}

This step involved the design or drafting of an action plan based on the Future State Map that was created at the previous step. An AP in general includes the following information: 1) First, information regarding the project of the application of the suggested improvements, such as the title and description of the action, its goals and objectives, the responsible process managers / supervisors and the timeframe / scheduling, and 2) Second, information regarding the examined business (production and logistics) processes, such as the title, description, status (not started, in progress, completed), impact, and priority. Table 5 (Action Plan Management of actions) in the Appendix presents the above information.

\section{Discussion - Conclusions}

This paper provides an application of the Lean thinking tools to support the green supply chain and logistics management initiatives. Authors argue that the VSM analysis can be an effective and efficient tool for a number of improvements not only for the identification of the wastes but for the determination of the greening of the agrifood supply chain. It suggests a systematic (four-step) approach that consists of specific tasks and activities.

A number of to-do (improvement) practices are proposed. Each of the improvement activities aimed at either eliminating non-value adding steps in order to reduce on the length of the value stream which subsequently would contribute to the reduction of the total process, lead and customer query cycle times and consequently the energy consumption and water usage. The proposed systematic approach was deployed in the canned peach production. After the preparation of the Action Plan (AP) the following achievements have been realized:

Today, canned peach production is achieved by peeling with sodium hydroxide solution at $95 \mathrm{oC}$. However, peeling by steam, which is an alternative peeling process, may have great benefits regarding water consumption and energy usage.

Insulation of piping and vessels, where heating or cooling is involved can further reduce steam consumption and therefore energy usage.

The kernels formed during the cutting in halves process can also be used for the production of energy, thus covering the energy requirements of other products that are produced on a small scale (e.g. peach puree and peach juice).

Finally, the wastes (peels) that derive after peeling can be used for animal feed and if steam peeling instead of chemical peeling is used, then no neutralization step is necessary.

Considering the findings that were observed following the implementation of the pilot project at the examined company, the research project provided viable evidence that these Lean techniques and principles have a positive impact on and that VSM was a workable technique in the production and logistics operations. There are also many challenges that need to be considered for future study regarding the examined sector. Introducing global supply chain management into the green and lean equation increases the potential conflict between the green and lean initiatives. So as companies begin 
to implement lean and green strategies in supply chains, especially large and complex global supply chains, manufacturers need to explore the overlaps and synergies between quality-based lean and environmentally based 'green' initiatives, and understand the various trade-offs required to balance possible points of conflict. Finally, there is a need to evaluate and possibly improve this tool, based on practice and the applicability in other sectors as well.

\section{Acknowledgment}

This research has been co-financed by the European Union (European Social Fund - ESF) and Greek national funds through the Operational Program "Education and Lifelong Learning" of the National Strategic Reference Framework (NSRF) - Research Funding Program: THALES. Investing in knowledge society through the European Social Fund (No. OPS 379411).

\section{References}

Abdulmalek, F. and J. Rajgopal. 2007. Analyzing the benefits of lean manufacturing and value stream mapping via simulation: A process sector. International Journal of Production Economics, 107:1:223-236. doi:10.1016/j.ijpe.2006.09.009

Belokar, M., Kumar, V. and S. Kharb. 2012. An Application of Value Stream Mapping In Automotive Industry: A Case Study. International Journal of Innovative Technology and Exploring Engineering (IJITEE) ISSN: 22783075, Volume-1, Issue-2, July 2012.

Beresford, A.K.C. and S.J. Pettit. 2004. The development of an emergency relief logistics response model. Proceedings of the 9th Logistics Research Network Conference, 300-310, Dublin.

Burrows, G. 1996. Production of thermally processed and frozen fruit. In: Fruit Processing. (D. Arthey and Ashurst, P.R., Eds.), pp.135-164, Blackie Academic \& Professional: London, UK. doi: $10.1007 / 978-1-4615-2103-7 \_6$

Chow, G., Heaver, T.D. and L.E. Henriksson. 1994. Logistics performance: Definition and measurement. International Journal of Physical and Distribution Management 24 (1), 17-28. doi:10.1108/09600039410055981

Cox, A. and D. Chicksand. 2005. The limits of Lean Management Thinking: Multiple Retailers and Food and Farming Supply Chains. European Management Journal, 23(6):648-662. doi:10.1016/j.emj.2005.10.010

Davenport, T.H. 1993. Process Innovation: Reengineering Work through Information Technology. Boston, Massachusetts: Harvard Business School Press. doi:10.1111/j.1467-9310.1995.tb01348.x

Dervitsiotis, K. 2006. Production management. 4th Edition, Oikonomiki Vivliothiki, Athens [in Greek]; 2006.

Dinesh, S., Nitin, S. and G. Deepak. 2008. Application of value stream mapping (VSM) for minimization of wastes in the processing side of supply chain of cottonseed oil industry in Indian context. Journal of Manufacturing Technology Management, Vol. 19 Iss: 4, pp.529-550. doi:10.1108/17410380810869950

Emiliani, L. and D. Stec. 2004. Using value-stream maps to improve leadership. The Leadership and Organization Development Journal, 25:8:622-645. doi:10.1108/01437730410564979

EPA, 2007. The Lean and Energy Toolkit. Energy', 2007;56.

Florida, R. 1996. Lean and green: the move to environmentally conscious manufacturing. California Management Review, 39:1:80-105. doi:10.2307/41165877

Folinas, D., Kelemis, A. and I. Manikas. 2011. A generic methodology for the prioritization of logistics processes: The case of the agrifood supply chain. Proceedings of the International Conference Management of Technology, Step to Sustainable Production (MOTSP 2011), 8-10 June 2011, Croatia; 2011.

Hines, P., Found, P., Griffith, G. and R. Harrison. 2008. Staying lean: thriving, not just surviving. Lean Enterprise Research Centre: Cardiff.

Ioannou, G. 2005. Management of production and services. Stamoulis, Athens [in Greek].

Joshi, V.K. and V.P. Bhutani. 1995. Peach and nectarine. In: Handbook of Fruit Science and Technology (D.K., Salunkhe and S.S. Kadam, Eds.), pp. 243-296. Marcel Dekker, Inc.: New York, NY, USA.

Karagiovannis, G. 2014. Personal communication. Mechanical Engineer at Kronos, S.A., Mavrovouni, Pella, Greece. 
King, A. and J. Lenox. 2001. Lean and green? An empirical examination of the relationship between lean production and green. Production and Operations Management, 10:3:244-251. doi:10.1111/j.1937-5956.2001.tb00373.X

Laguna, M. and J. Marklund. 2004. Business Process Modeling, Simulation and Design. Prentice Hall, New Jersey.

Lasa, I.S., Laburu, C.O. and R. de C. Vila. 2008. An evaluation of the value stream mapping tool. Business Process Management Journal, 14(1), pp.39-52. doi:10.1108/14637150810849391

US EPA. 2003. Lean Manufacturing and the Environment: Research on Advanced Manufacturing Systems and the Environment and Recommendationsfor Leveraging Better Environmental Performance.

Madison, D. 2005. Process Mapping, Process Improvement and Process Management, Paton Press.

Plenert, G. 2007. Reinventing Lean- Introducing Lean Management into the Supply Chain, Burlington: Butterworth-Heinemann.

Pretty, JN., Ball, AS., Lang, T. and I.L. Morison. 2006. Farm costs and food miles: an assessment of the full cost of the UK weekly food basket. Food Policy, 30:6:1-19. doi:10.1016/j.foodpol.2005.02.001

Rakshit H., Lewlyn L. and R. Rodrigues. 2013. Lean transformation for green and financially viable foundries. International Journal of Mechanical and Production Engineering (IJMPE), Vol-2, Iss-1, pp. 118-134.

Rothenberg, S., Pil, K. and J. Maxwell. 2001. Lean, green, and the quest for superior environmental performance. Production and Operations Management, 10:3:228-243. doi:10.1111/j.1937-5956.2001.tb00372.x

Rother, M. and J.Shook. 2003. Learning to see. Lean Enterprise Institute.

Simons, D. and Mason, R. (2002) Environmental and Transport Supply Chain Evaluation with Sustainable VSM, Proceedings of the 7th Logistics Research Network Conference, Birmingham, UK.

Simons, D., Mason, R. and U. Cardiff 2003. Lean and green: doing more with less. ECR Journal, 2003, 3: 84-91.

Simpson, F. and J. Power. 2005. Use the supply relationship to develop lean and green suppliers. SCM: An International Journal, 10:60-68. doi:10.1108/13598540510578388

Sistrunk, W.A. 1985. Peach quality. In: Evaluation of Quality of Fruits and Vegetables. (H.E. Pattee, Ed.), pp. 146, AVI Publishing Company: Westport, CT, USA. doi:10.1007/978-94-009-4217-2_ 1

Tanco, M., Santos, J., Rodriguez, J. and J. Reich. 2013. Applying lean techniques to nougat fabrication: a seasonal case study. The International Journal of Advanced Manufacturing Technology, 68:5-8, pp. 1639-1654. doi: $10.1007 / \mathrm{s} 00170-013-4960-7$

Torres, A.S. and A.M. Gati. 2009. Environmental Value Stream Mapping (EVSM) as sustainability management tool. International Conference on Management of Engineering \& Technology, PICMET 2009, Portland, 2-6 Aug. 2009. doi: $10.1109 /$ picmet.2009.5261967

Uhrig, J. and D. Maier. 1992. Costs of Drying High-Moisture Corn. Cooperative Extension Service Purdue University.

Venkat, K. and W. Wakeland. 2006. Is Lean Necessarily Green?. Proceedings of the 50th Annual Meeting of the ISSS, ISSS 2006 Papers.

Womack, J.P. and D.T. Jones. 1996. Beyond Toyota: How to root out waste and pursue perfection. Harvard business review, 74(5): 140-150.

Yang, C., Lin, S., Chan, Y. and C. Sheu. 2010. Mediated effect of environmental management on manufacturing competitiveness: An empirical study. International Journal of Production Economics, 123:210-220.

doi:10.1016/j.ijpe.2009.08.017 


\section{Appendix}

Table 5. Facts and assumptions

- Focus on canned peach production / There is no IT system for designing and managing the materials in the production line

- Start/End of canned peach production: July-end of September/Working hours: $23 \mathrm{~h}$ Appr. 10,500 cans/production line/h are produced. Each can weighs $1 \mathrm{~kg}$

- Factory operates: 60 days x $23 \mathrm{~h} /$ day $=1380 \mathrm{~h} /$ Assuming that all engines have an average performance of $80 \%$ / Reception: 45 lorries / 21 tn on a daily basis /

packaging materials are procured from local producers / 90\% of the total orders are exported / no problems associated with over-production

\begin{tabular}{|c|c|c|c|c|c|}
\hline Processing step & $\begin{array}{l}\text { Number of } \\
\text { employees }\end{array}$ & $\begin{array}{c}\text { Processing } \\
\text { time }(\mathrm{min} / \mathrm{tn})\end{array}$ & Installed capacity & $\begin{array}{c}\text { Energy consumption (per tn) } \\
\text { Oil and electricity } \\
\end{array}$ & Scrap $(\%)$ \\
\hline $1^{\text {st }}$ Washing & 5 & $10-15^{\prime}$ & & $5 \%$ of total electrical energy & N/A \\
\hline $\begin{array}{l}\text { Cutting in halves/Kernel } \\
\text { removal }\end{array}$ & 3 & 1 ' & & $<5 \%$ of total electrical energy & Kernels \\
\hline Peeling & 1 & $4-5$ & $15 \mathrm{~kW}$ motor & $\begin{array}{l}30 \% \text { of total steam consumption } \\
1650 \mathrm{kWh} / \text { production line }\end{array}$ & N/A \\
\hline $2^{\text {nd }}$ Washing & & 1 ' & $10 \mathrm{~kW}$ motor & $1104 \mathrm{kWh} /$ production line & Peels \\
\hline Sorting & & 0,5 & $3 \times 5.5 \mathrm{~kW}$ motor & $\begin{array}{c}18216 \mathrm{kWh} \text { (for all production lines) - } \\
1821.6 \mathrm{kWh} / \text { production line }\end{array}$ & N/A \\
\hline $\begin{array}{c}\text { Cup-up (residual kernel } \\
\text { removal) }\end{array}$ & $\begin{array}{l}5 / \text { production } \\
\text { line }\end{array}$ & 2 ' & $1 \mathrm{x} 5 \mathrm{~kW}$ motor & $5520 \mathrm{kWh}$ & N/A \\
\hline Cup-down & $\begin{array}{l}\text { 8/production } \\
\text { line }\end{array}$ & 3 & $1 \times 5 \mathrm{~kW}$ motor & $5520 \mathrm{kWh}$ & N/A \\
\hline Filling with fruit & $\begin{array}{l}\text { 4/production } \\
\text { line }\end{array}$ & - & $1 \times 5 \mathrm{~kW}$ motor & $5520 \mathrm{kWh}$ & N/A \\
\hline Addition of syrup & & - & $1 \times 5 \mathrm{~kW}$ motor & $5520 \mathrm{kWh}$ & N/A \\
\hline Degassing & & $10^{\prime}$ & $1 \times 5 \mathrm{~kW}$ motor & $5520 \mathrm{kWh}$ & N/A \\
\hline Closing & & 0,5 & $1 \times 5 \mathrm{~kW}$ machine & $5520 \mathrm{kWh}$ & N/A \\
\hline Pasteurizing & & $20^{\prime}$ & $15 \mathrm{~kW}$ motor & $5520 \mathrm{kWh}$ & N/A \\
\hline Cooling & & $20^{\prime}$ & $1 \mathrm{x} 45 \mathrm{~kW}$ motor & $\begin{array}{c}60 \% \text { of total steam consumption } \\
\text { (4968 kWh/production line for pumps) }\end{array}$ & N/A \\
\hline Palletizing/Labeling & 1/prod. line & $7-8$ & & & N/A \\
\hline Total & 27 & $79^{\prime}-86^{\prime}$ & & $50391.6 \mathrm{kWh} /$ production line & \\
\hline Addition of syrup & & & $\begin{array}{l}1 \mathrm{x} 2 \mathrm{~kW} \text { motor for } \\
\text { stirrer }\end{array}$ & $\begin{array}{c}10 \% \text { of total steam consumption } \\
2208 \mathrm{kWh} / \text { production line }\end{array}$ & N/A \\
\hline
\end{tabular}


Figure 2. Current State Map

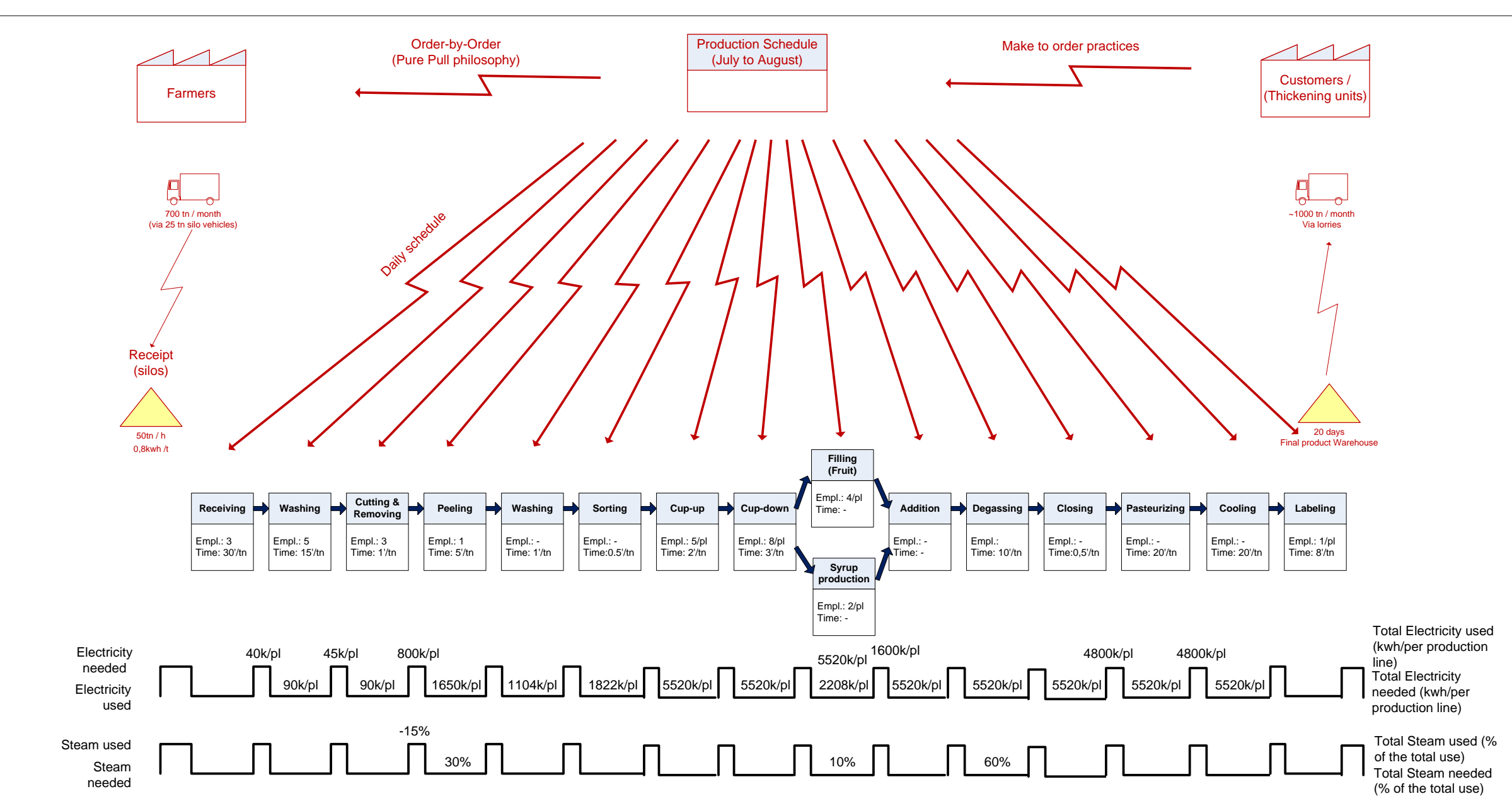


Figure 3. Future State Map

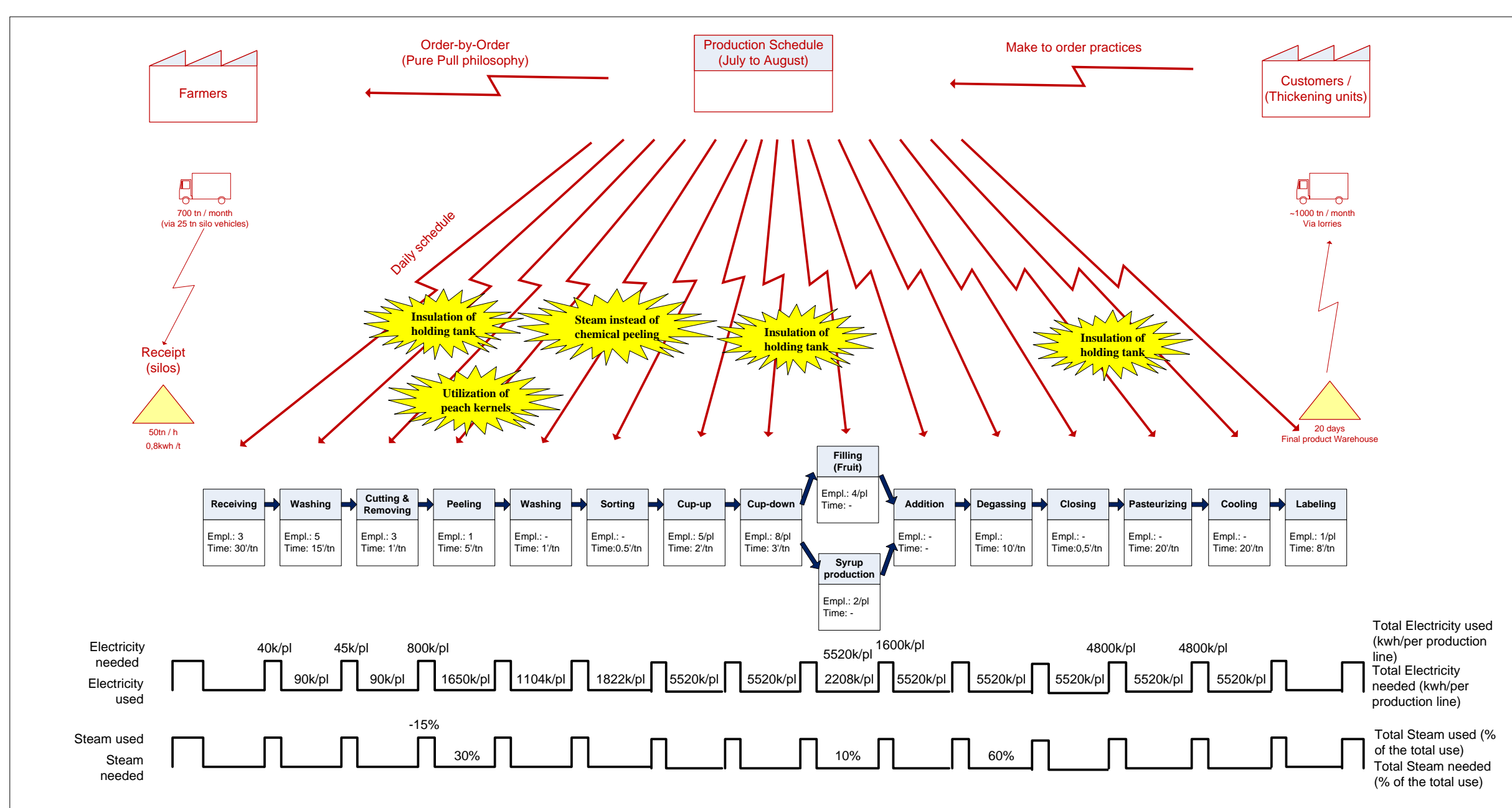


Table 6. Action Plan Management of actions

\begin{tabular}{|c|c|c|c|c|c|c|c|}
\hline $\begin{array}{l}\text { Title / } \\
\text { Area }\end{array}$ & Description & Action & $\begin{array}{l}\text { Impact } \\
\text { L=Low } \\
\text { M=Medium } \\
\text { H=High }\end{array}$ & $\begin{array}{l}\text { Priority } \\
\text { 1=Low } \\
\text { 2=Medium } \\
\text { 3=High }\end{array}$ & Supervisor & $\begin{array}{l}\text { Time } \\
\text { scheduling }\end{array}$ & $\begin{array}{l}\text { Status } \\
\mathrm{N}=\text { not started } \\
\mathrm{I}=\mathrm{in} \text { progress } \\
\mathrm{C}=\text { completed }\end{array}$ \\
\hline Production & Washing & $\begin{array}{l}\text { Insulation of holding tank and } \\
\text { piping }\end{array}$ & $\mathrm{L}$ & 1 & $\begin{array}{l}\text { Production } \\
\text { Manager }\end{array}$ & & $\mathrm{C}$ \\
\hline Production & $\begin{array}{l}\text { Cutting in } \\
\text { halves }\end{array}$ & $\begin{array}{l}\text { Utilization of peach kernels for } \\
\text { energy production }\end{array}$ & $\mathrm{M}$ & 2 & $\begin{array}{l}\text { Production } \\
\text { Manager }\end{array}$ & & I \\
\hline Production & Peeling & $\begin{array}{l}\text { Substitute the current chemical } \\
\text { peeling process with steam } \\
\text { peeling }\end{array}$ & $\mathrm{H}$ & 3 & $\begin{array}{l}\text { Production } \\
\text { Manager }\end{array}$ & & I \\
\hline Production & Peeling & $\begin{array}{l}\text { Insulation of holding tank and } \\
\text { piping }\end{array}$ & $\mathrm{H}$ & 3 & $\begin{array}{l}\text { Production } \\
\text { Manager }\end{array}$ & & $\mathrm{C}$ \\
\hline Production & Syruping & $\begin{array}{l}\text { Insulation of holding tank and } \\
\text { piping }\end{array}$ & $\mathrm{H}$ & 3 & $\begin{array}{l}\text { Production } \\
\text { manager }\end{array}$ & & $\mathrm{C}$ \\
\hline Production & Pasteurizing & $\begin{array}{l}\text { Insulation of holding tank and } \\
\text { piping }\end{array}$ & $\mathrm{H}$ & 3 & $\begin{array}{l}\text { Production } \\
\text { Manager }\end{array}$ & & $\mathrm{C}$ \\
\hline Production & Cooling & $\begin{array}{l}\text { Insulation of holding tank and } \\
\text { piping }\end{array}$ & $\mathrm{L}$ & 1 & $\begin{array}{l}\text { Production } \\
\text { Manager }\end{array}$ & & $\mathrm{C}$ \\
\hline
\end{tabular}

